\title{
In memoriam G. Fekete Éva
}

\author{
In memoriam Éva G. Fekete
}

DABASI-HALÁSZ ZSUZSANNA, LIPTÁK KATALIN

\begin{abstract}
DABASI-HALÁSZ Zsuzsanna: egyetemi docens, Miskolci Egyetem, Világ- és Regionális Gazdaságtan Intézet; 3515 Miskolc-Egyetemváros; hrdabasi@uni-miskolc.hu LIPTÁK Katalin: egyetemi adjunktus, Miskolci Egyetem, Világ- és Regionális Gazdaságtan Intézet; 3515 Miskolc-Egyetemváros; liptak.katalin@uni-miskolc.hu
\end{abstract}

\begin{abstract}
Zsuzsanna DABASI-HALÁSZ: associate professor, Institute of World and Regional Economics, University of Miskolc; H-3515 Miskolc-Egyetemváros, Hungary; hrdabasi@uni-miskolc.hu Katalin LIPTÁK: assistant professor, Institute of World and Regional Economics, University of Miskolc; H-3515 Miskolc-Egyetemváros, Hungary; liptak.katalin@uni-miskolc.hu
\end{abstract}

Nagy formátumú kutatót, oktatót veszítettünk el 2017. április 23-án. 57 évesen tele tervekkel, félbehagyott kutatásokkal kellett elmennie. Egész élete az ALKOTÁS-ról szólt, a megoldások kereséséről. Ízig-vérig tanáregyéniségként akkor érezte magát igazán jól, ha gondolatait megoszthatta tanítványaival, munkatársaival. Egyforma közvetlenséggel magyarázta elképzeléseit nekünk, kollégáknak, a tudományos közéletnek, az egyetemistáknak vagy az utca emberének. Minden munkájában úgy rejlett ott a tudományosság igénye, hogy közben segíteni akart a szeretett csereháti térségnek, az ott élőknek. Saját szavaival megfogalmazva „a lényeg, hogy vegye komolyan, hogy akarjon valamiféle társadalmi ügy mögé odaállni." ő egész életével odaállt, kutatott, írt, tanított, hogy a hátrányos vidékek is fejlődhessenek. Az együttmüködés volt életének egyik vezérfonala. Így fogalmazott egyik munkájában: „A partnerség alapja a közös érdek felismerése és a bizalom a partnerekben. Mindkettő egymás kölcsönös megismeréséből nőhet ki." A magyar vidék, a magyar vidéki élet, a magyar vidéki emberek elvesztették az egyik legkiválóbb kutatót, aki az ő problémáikkal foglalkozott, aki felhívta a figyelmet a gondokra és aki megoldási javaslatokat nyújtott, tevékeny résztvevőként mutatta meg a kivezető utat a társadalmi innovációk, a helyi fejlesztések révén.

Három munkahelye volt, az Izsó Miklós Gimnáziumban tanári és igazgatóhelyettesi munka után az MTA Regionális Kutatások Központja Észak-Magyarországi Osztályának segédmunkatársa, kutatója majd osztályvezetője volt és 1996-tól részmunkaidős adjunktusa, majd 2008-tól foállású docense, egyetemi tanára a Miskolci Egyetem Gazdaságtudományi Kar Világ- és Regionális Gazdaságtan Intézetének. Az utóbbi években a Munka- és Társadalom-gazdaság-

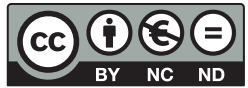


tan Tanszék vezetőjeként dolgozott fáradhatatlanul, hallatlan szorgalommal és tehetséggel.

Kutatási témáját maga így fogalmazta meg; „Elmaradott térségek, perifériák, aprófalvak társadalmi és gazdasági sajátosságainak vizsgálata. Munkaerőpiaci folyamatok leírása és azon belül a helyi és kistérségi gazdaság és foglalkoztatás fejlesztésének lehetőségeinek keresése. A vidékfejlesztés különböző kérdéseinek részvételi akciókutatása. A szociális gazdaság és a szolidáris gazdaság elméleti és gyakorlati vizsgálata."

A diploma megszerzését követő harmadik évben megvédte egyetemi doktori értekezését a Bódva-völgy népességmegtartó képessége témájában (1986). 1987-től az MTA Regionális Kutatások Központja akkor alakult Északmagyarországi Osztályán dolgozott. Az ott eltöltött több mint 20 év alatt több mint 50 területi kutatásban vett részt. Kandidátusi dolgozata az 1987-1994 közötti, a helyi fejlesztés témaköréhez kapcsolódó kutatások eredményeit foglalja össze. Az értekezés témaválasztását a bizonytalanságok tisztázására irányuló törekvés, valamint a kutatásban kiemelt szerepet játszó térség, a Cserehát, az ott élő emberek sorsa iránti elkötelezettség motiválta. Az eredmények helyi fejlesztésre, kistérségi szerveződésekre vonatkozó része a Kistérségi szerveződések megjelenése a területfejlesztésben című könyvben került a nyilvánosság elé (G. Fekete, Bodolai 1995). A Cserehátra vonatkozó eredmények az A térség, mely élni akar című térségfejlesztési programba (G. Fekete, Francsics 1996) épültek be, és a kistérség fejlesztésének máig forgatott kézikönyvéül, a további stratégiák kidolgozásának és a Cserehátra több mint 1,5 milliárd Ft-ot hozó fejlesztési projektsorozat megvalósításának alapjául szolgáltak. Az esélyegyenlőség, társadalmi kirekesztődés, romák témakörében végzett kutatások a területi hátrányok halmozott voltának feltárásához vitték közelebb. A vidéki térségek, ezen belül az aprófalvak kutatása a méret és a hátrány közötti összefüggések feltárását célozta. A helyi fejlesztés lehetséges technikáinak kutatása a korábbi szervezeti-módszertani témákon túl a vidékfejlesztés, a kulturális és a szociális gazdaság, a helyi foglalkoztatás kérdései irányába terelte az érdeklődését. E kutatási témákra egységesen jellemző, hogy a gazdaság- és a társadalomfejlesztés határmezsgyéjén állnak és kutatásuk leginkább „puha” módszerekkel lehetséges. Éva a módszertani dualizmus elvét vallotta, kvantitatív énje objektív adatokkal számolt, míg a kvalitativitás számára még érdekesebb volt, megfigyelt, kérdezett, beszélgetett. Kritikai geográfusként a megismerni és megváltoztatni volt a fő mottója. Hitt a részvételi akciókutatás módszertanában, abban az értelemben, ahogyan az „akciókutatás” lényege megpróbálni újra összekapcsolni a cselekvést a reflexióval, az elméletet a gyakorlattal, másokkal együttműködésben, az embereket foglalkoztató problémák gyakorlati megoldásait keresve. A részvételi akciókutatás a közösségeket érintő döntéshozatali folyamatokban való részvételt helyezi középpontjába. A lehetőségek szerint az összes releváns szereplőt bevonja a valamilyen szempontból problémásnak ítélt helyzet értékelésébe abból a célból, hogy változáso- 
kat és konkrét cselekvéseket hozzon létre. Ez jellemezte G. Fekete Éva munkáját: végtelenül szerényen, mindenki véleményére odafigyelve, de tudását határozottan mások boldogulására fordítva igyekezett szeretett csereháti térségének lakóin segíteni. 2012-ben habilitációs értekezésében összefoglalta az elmúlt 15 évben végzett foglalkoztatási témájú kutatásainak az eredményét, amelyet A vidéki munkanélküliség tömegessé válásától az új foglalkoztatási modellekig: Tizenöt év foglalkoztatási tárgyú kutatásai címmel jelentette meg (G. Fekete 2015). Tanulmányaival, könyveivel maradandót alkotott, amely írások nemcsak az akadémiai szféra számára fontos olvasmányok, hanem a hallgatóknak, az érdeklődőknek is.

Oktatott tantárgyaira az alapos rendszerszemlélet, az erős szakirodalmi háttér és a sok, színes gyakorlati példa volt jellemző. Többek között Vidékfejlesztést, Regionális programozást és menedzsmentet, Helyi foglalkoztatásfejlesztést, A társadalom térszerkezetét, Gazdaságföldrajzot tanított közgazdász és geográfus hallgatóknak, akik mindig nagy érdeklődéssel fogadták előadásait. Lelkesedése egy-egy téma iránt a hallgatóságra is gyorsan átragadt. Munkássága alatt több tucat szakdolgozatot, OTDK-dolgozatot vezetett és doktori témavezetőként is segítette a fiatalok munkáját.

Három nemzetközi és tizenkét hazai tudományos, szakmai társaságnak, köztük az MTA IX. Osztály Regionális Tudományi Bizottságának volt a tagja. Országosan elismert szakemberként tartották számon a vidék- és helyi fejlesztés, valamint a szociális gazdaság témájában, amit Pro Régió-díjjal, Kemény Bertalan Falufejlesztési Díjjal és más szakmai elismerésekkel, konferenciameghívásokkal ismertek el. Nemzetközi ismertsége Kelet-Közép-Európában a vidékfejlesztés, Nyugat-Európában a szociális gazdaság témakörében volt számottevőbb. Tagja volt a RIPESS (Hálózat a Szolidáris és Szociális Gazdaság Támogatásáért) nyolcfös európai koordinációs bizottságának. Az általa 2004 óta szerkesztett Észak-magyarországi Stratégiai Füzetek elismert szakmai folyóirattá vált, szerzői és olvasói köre immár nemzetközi kiterjedésű. ő kezdeményezte és szervezte a Miskolci Egyetem Világés Regionális Gazdaságtan Intézete által gesztorált Margó esettanulmány-készítő versenyt és az „irotai” Periféria Nyári Egyetemet.

G. Fekete Éva színes egyéniség volt, gazdag kutatások jellemzik munkásságát. Egyszerre volt elméleti szakember és innovatív gondolkodó. Szellemi hagyatékát és emlékét méltó alázattal igyekszünk megőrizni a tananyagokban, tanszéki beszélgetésekben, anekdotákban, tudományos munkáinkban.

\section{Irodalom}

G. Fekete É. (2015): A vidéki munkanélküliség tömegessé válásától az új foglalkoztatási modellekig: Tizenöt év foglalkoztatási tárgyú kutatásai. Herman Ottó Intézet, Budapest 
G. Fekete É., Bodolai É. (1995): Kistérségi szerveződések megjelenése a területfejlesztésben. MTA Regionális Kutatások Központja, Pécs, Miskolc (Együtt! - De hogyan?; 1.)

G. Fekete É., Francsics L. (1996): A térség mely élni akar. Cserehát-Hernád-Bódva vidék Térségfejlesztési Program. MTA Regionális Kutatások Központja, Miskolc

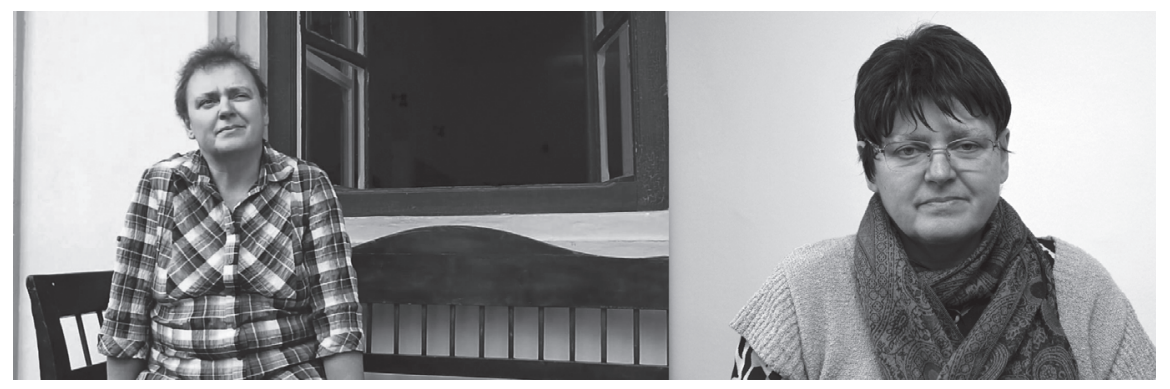

